\title{
Sijoituslannoituksen kehityksestä ja tutkimustoiminnasta Suomessa
}

\author{
OSMO KARA ja LASSI RÄISÄNEN \\ Maatalouskoneiden tutkimuslaitos, Rukkila, 00001 Helsinki
}

On the development and field experiments of fertilizer placement in Finland

Osmo KARA and LASSI RÄISÄNEN

Finnish Research Institute of Engineering in Agriculture and Forestry, Rukkila, 00001 Helsink

\begin{abstract}
The placement of fertilizer in connection with sowing of cereal has become very popular in Finland within the last 10 years. Today we generally place fertilizer and drill seed at the same time with a fertilizer placement drill, which drills seed to rows and places fertilizer between every other row. We also use machines, fertilizer and seed drills, with which the sowing and the fertilizer placement are done with the same coulters in different operations. Shares of the drill coulters can also be turnable so that one end is a fertilizer coulter and the other a seed coulter. The sale of fertilizer placement drills is at present about 10 times larger than the total sale of traditional seed drills in Finland.

There have been many field experiments in the placement of fertilizer with spring cereals in Finland.

The placement of fertilizer into a depth of $8-10 \mathrm{~cm}$ has increased grain yields of spring cereals on an average about 14 percent. The increase in grain yields has varied between $0-40 \%$ in different yers.

The placement of fertilizer has improved most the availability of nitrogen, next of potassium and then of phosphorus. The placement has also accelerated ripening. The crude protein content of the grain yield has decreased somewhat by the placement of fertilizer.

Sprinkler irrigation did not appear to reduce the effect of placement of the fertilizer. These two methods form a highly efficient combination.
\end{abstract}

\section{Sijoituslannoituskoneiden kehityksestä}

Lannoitteen sijoittaminen samaan riviin siemenen joukkoon tai määräetäisyydelle siemenestä on ollut tunnettu jo viime vuosisadalla ja on yleisessä käytössä mm. Yhdysvalloissa. Euroopassa ensiksi mainittu menetelmä yleistyi jossain määrin toisen maailmansodan aikana Englannissa. Pohjoismaissa viljan viljelyyn liittyviä sijoituslannoitusta koskevia tutkimuksia alettiin suorittaa 1940-luvulla. Alustavien tutkimusten perusteella mm. Ruotsissa 
julistettiin v. 1946 suunnittelukilpailu erillisen rivilannoittimen kehittämiseksi. Suunnitellut koneet jäivät kuitenkin kokeiluasteelle.

Suomessa Ma a s u d n K o n e valmisti v. 1955 siementen joukkoon lannoitteet kylvävän hevos- ja traktorivetoisen kylvölannoittimen koekappaleet. Koneiden vastaanotto oli kuitenkin siinä määrin ristiriitainen, että valmistaja katsoi parhaaksi jäädä odottamaan lisäselvityksiä.

Vuonna 1957 ahvenanmaalainen maanviljelijä C. N o r d l u n d rakensi yhdistetyn kylvökoneen, johon oli yhdistetty myös muokkauskone ja jyrä. Tämäkään kone ei päässyt teollisen valmistuksen asteelle.

Vaikka maassamme myytiinkin ulkomaisia lannoitteen siementen joukkoon kylväviä koneita 1950-luvulla jonkin verran, menetelmä ei kuitenkaan yleistynyt. Tämä johtui ainakin osittain siitä, että kyseisten koneiden riviväli oli melko suuri eivätkä sadon lisäykset vastanneet odotuksia. Koneet olivat myös alttiita ruostumaan ja lyhytikäisiä.

Vuonna 1958 professori M a r t t i S a l o n e n suunnitteli kenttäkokeita, joiden tarkoituksena oli selvitellä ennen viljan kylvöä määräsyvyyteen sijoitetun lannoitteen vaikutusta. Tarkoitusta varten maatalouskoneiden tutkimuslaitoksella vahvistettiin hevosvetoinen viljankylvökone. Tämä vetovantainen kone oli kuitenkin heikkorakenteisena rivilannoitukseen sopimaton ja kokeet epäonnistuivat.

Seuraava varsinainen rivilannoittimen koekappale suunniteltiin ja rakennettiin kevättalvella 1959 maatalouskoneiden tutkimuslaitoksella yhteistoiminnassa Yliopiston maanviljelyskemian laitoksen kanssa. Tämän koekappaleen (kuva 1) suunnittelussa oli pyrkimyksenä rivilannoituksen ohella korvata osittain myös kylvömuokkaus samalla ajokerralla. Koneen runko-osana oli silmuk-

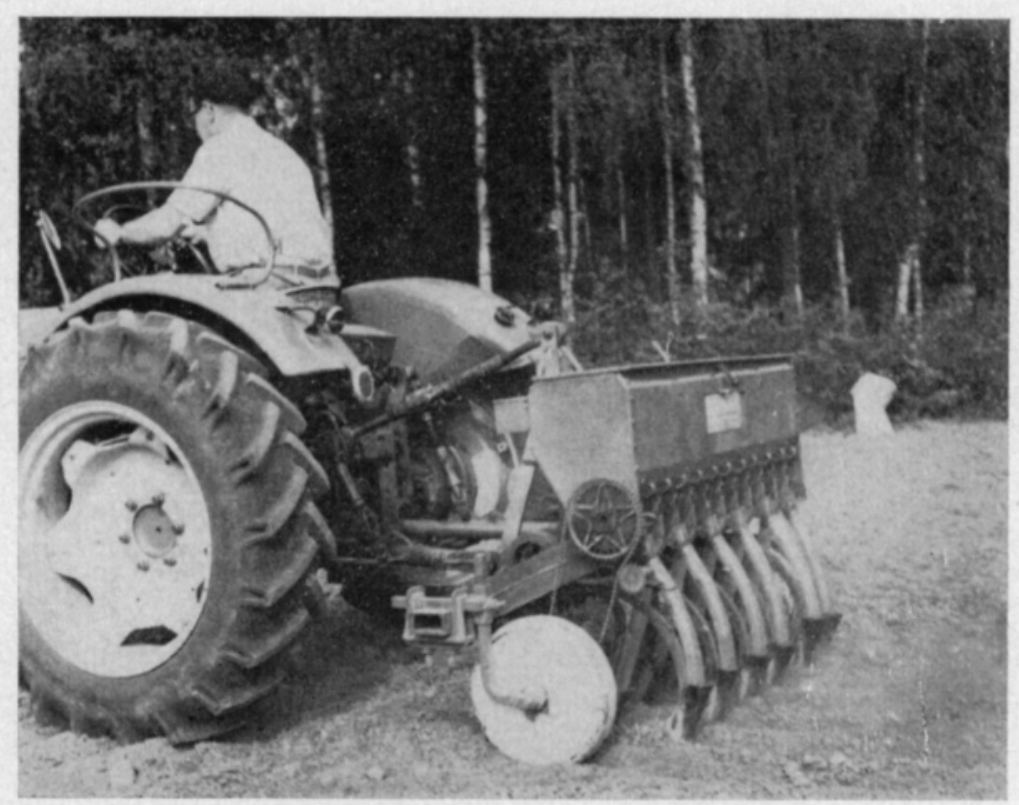

Kuva 1. Rivilannoituskoneen koekappale v. 1959.

Fig. 1. Experimental fertilizer placement drill in 1959. 
kakultivaattori ja syöttökoneistona viljankylvökoneen syöttölaite säiliöineen. Lannoiteputket johdettiin kultivaattorin terien taakse kiinnitettyihin suppiloihin. Koneen kokeilun yhteydessä suoritettiin alustavia kenttäkokeita melko ravinneköyhillä multa- ja hietamoreenimailla. Näissä alustavissa kokeissa sadon lisäykset olivat yllättävän suuria, keskimäärin noin $25 \%$ hajalannoitettuun verrattuna (Nieminen ja Heinonen 1960, Heinonen ja NiEminen 1961).

Em. rivilannoittimen lisäksi tutkittiin lähinnä koneiden kehittämisen suunnan selvittämiseksi myös lautasterin muokkaavien ja multaavien rivilannoittimien soveltuvuutta. Raskasrakenteisina koneet olivat kuitenkin hankalia käsitellä ja niiden edelleen kehittämisestä luovuttiin.

Alustavissa kokeissa saatujen myönteisten kokemusten jälkeen rivilannoittimien teolliseen valmistuskuntoon saattaminen ja jatkokehitys siirtyi pääasiassa maatalouskoneteollisuudelle. Vuonna $1961 \mathrm{~J}$ unnila n K o n ep a j a valmisti ensimmäisen teollisesti valmistetun S-piikein varustetun rivilannoittimen koekappaleen. Tehdasvalmisteisten koneiden myynti alkoi vuonna 1963, jolloin em. tehdas valmisti 15 rivilannoittimen koesarjan. Kahtena seuraavana vuonna erilliseen lannoitteen multaamiseen tarkoitettujen rivilannoittimien myynti oli vielä melko vähäistä, yhteensä n. 460. Tämän jälkeen myynti lisääntyi tuntuvasti.

Kylvö-lannoituskoneita (kuva 2), joilla lannoitus tapahtuu samalla ajokerralla kuin kylvö määräsyvyyteen ja -etäisyyteen siemenrivistä, on maassamme valmistettu myyntiä varten vuodesta 1966 alkaen. Koneet olivat aluksi lannoitteen jokaiseen kylvöriviväliin sijoittavia. Näitä koneita kehitettiin myös yliopiston koetilalla Malminkartanossa agr. Matti Kareksen toimesta. Koneen rakenteen yksinkertaistamiseksi ja tukkeutumisvaaran pienentämiseksi lannoitusvantaiden määrää vähennettiin niin, että kone sijoitti lannoitteet joka toiseen kylvöriviväliin. Kenttäkokein menetelmät todettiin likimain tasavertaisiksi. Nykyisin kaikki maassamme valmistetut kylvö-lannoittimet ovat viimeksi mainittua mallia.

Yleisvantaalla varustettuja rivilannoittimia, joilla kylvö ja lannoitus tapahtuu samalla koneella eri ajokerroilla, on myyty maassamme v. 1970

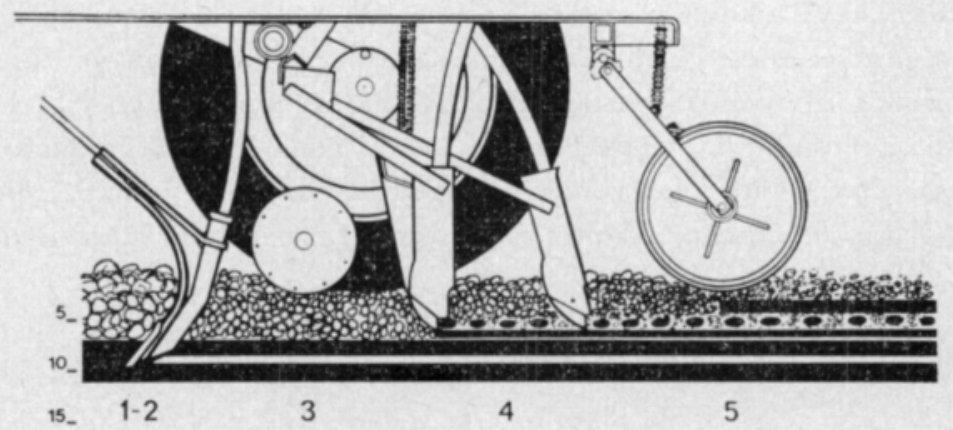

Kuva 2. Kylvölannoituskoneen kaaviokuva. 1-2) lannoitusvannas, 3) varpajyrä, 4) kylvövantaat ja 5) jyräpyörät.

Fig 2. Principle of fertilizer placement and seed drill with machines of the present time. 1-2) fertilizer drill, 3) rotary spiral-cage tiller, 4) seed drills, 5) press wheels. 
alkaen. Kone poikkeaa tavallisesta kylvökoneesta vain vantaan rakenteen suhteen. Jokainen painojousella varustettu vannas toimii kylvövantaan tapaan toisistaan riippumatta. Vantaan kärjen muoto on tehty ottavaksi lannoitteen riittävän sijoitussyvyyden saavuttamiseksi. Valmistetaan myös konemallia, jossa vannas voidaan kääntää sekä viljan kylvöä että lannoitusta varten.

Sijoituslannoitus- ja kylvökoneiden myynti maassamme käy ilmi taulukosta 1 .

Taulukko 1. Sijoituslannoitus- ja kylvökoneiden myynnin kehitys

Table 1. The development of the sale of seed drill and fertilizer placement machines in Finland

\begin{tabular}{|c|c|c|c|c|c|c|c|}
\hline & 1967 & 1968 & 1969 & 1970 & 1971 & 1972 & 1973 \\
\hline 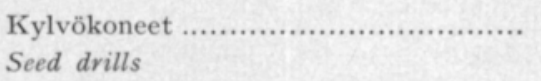 & 3370 & 2900 & 3000 & 2200 & 1560 & 1590 & $=410$ \\
\hline $\begin{array}{l}\text { Kylvö-lannoittimet ................................... } \\
\text { Combine placement drills }\end{array}$ & 100 & 200 & 570 & 2050 & 3000 & 2950 & 3480 \\
\hline $\begin{array}{l}\text { Rivilannoittimet } \\
\text { Fertilizer drills }\end{array}$ & 2170 & 2600 & 3000 & 2200 & 1460 & 570 & 430 \\
\hline $\begin{array}{l}\text { Yleisvannaskoneet .................................... } \\
\text { Fertilizer and seed drills }\end{array}$ & - & - & - & 100 & 200 & 600 & 1860 \\
\hline
\end{tabular}

Tilaston perusteella voidaan todeta, että kylvö-lannoituskoneiden ja ns. yleisvannaskoneiden käytön yleistyttyä varsinaisten kylvökoneiden myynti on pienentynyt romahdusmaisesti, kuten myös varsinaisten rivilannoittimienkin. Arvion mukaan nykyisin n. $70 \%$ kevätviljoista lannoitetaan lannoitteet maahan sijoittaen, ja kehityksen suunnan jatkuessa tultaneen tällä vuosikymmenellä viljakasvien hajalannoituksesta maassamme lähes tyystin luopumaan.

\section{Sijoituslannoitusta koskevat tutkimukset}

Useissa tutkimuksissa on todettu, että äkeellä syväänkin muokattaessa lnnoitteet jäävät $0-\mathbf{5} \mathrm{cm}$ syvyyteen, siis kylvö- ja juurikerroksen yläpuolelle. Kuivan alkukesän aikana, mikä on oloissamme tyypillistä, suurin osa äkeellä mullatusta amoonium- ja nitraattitypestä pysyttelee maan pintakerroksissa ja on kasveille alkukehityksen aikana käyttökelvotonta (KAILA ja HännineN 1961). Maan pinnalle levitetyn typen teho on vielä äkeellä mullattuakin huonompi (SALONEN 1960). Sateisinakaan kausina suuri osa huonosti liikkuvasta kylvömuokkauskerrokseen sekoitetusta fosforista ei joudu juurten ulottuville.

Lannoitteiden kylvö siementen joukkoon

Eri maissa suoritetuissa tutkimuksissa on voitu todeta, että samaan riviin siementen joukkoon sijoitettujen pienehköjen superfosfaattimäärien lannoitusteho on lisääntynyt tuntuvasti vastaaviin hajalannoituksena annettuihin määriin verrattuna. HonkavaARan (1945) suorittamissa kokeissa $50 \mathrm{~kg}$ superfos- 


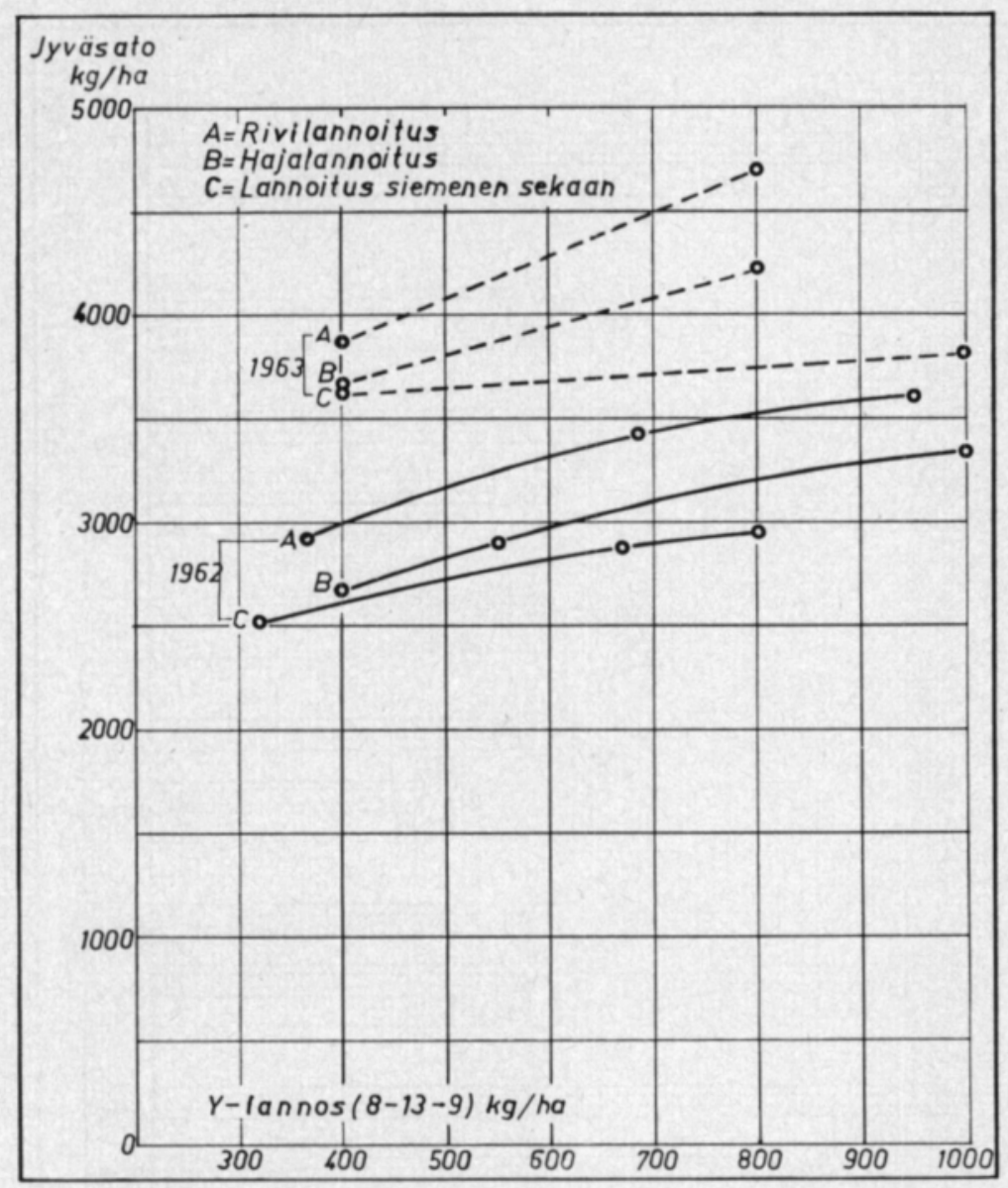

Kuva 3. Samaan riviin siemenen kanssa sijoitetun lannoitteen vaikutus jyväsadon määrään verrattuna erilliseen rivilannoitukseen ja hajalannoitukseen (Svenno-kevätvehnä).

Fig. 3. Effect of fertilizer placement. A) Fertilizer placed in rows in different operations, B) broadcast, and C) fertilizer and drill seed placed in the same row.

faattia lisäsi lannoittamattomaan verrattuna hajalevittäen satotasoa $250 \mathrm{~kg} / \mathrm{ha}$ ja siementen joukkoon kylvettynä $500 \mathrm{~kg} / \mathrm{ha}$.

Niemisen (1964) suorittamissa kokeissa (kuva 3) lannoitustason vaihdellessa välillä $300-1000 \mathrm{~kg} /$ ha Y-lannosta $(8-13-9)$ lannoite pantuna siemenen joukkoon on antanut sekä hajalannoitettuja, mutta etenkin rivilannoitettuja koejäseniä pienempiä satoja. Lannoitustason noustessa satoerot ovat suurentuneet tuntuvasti rivilannoituksen eduksi. Myös Ruotsissa on saatu saman suuntaisia tuloksia (HEINONEN 1965). Kotkaniemen koetilalla suoritetuissa kokeissa lannoitustasoilla 450 ja $700 \mathrm{~kg} / \mathrm{ha}$ Y-lannosta $(15-20-15)$ lannoite siemenen joukkoon kylvettynä ja rivilannoittaen ovat em. tuloksista poiketen antaneet likimain yhțä suuret sadot. (PEssi ym. 1970).

Lannoitteiden sijoittamistavan ja sadetuksen vaikutusta koskevien tutkimuksien perusteella vaikuttaa siltä, että mitä kuivempi kasvukausi on sitä haitallisempaa on sijoittaa lannoite samaan riviin kylvösiemenen kanssa. (KARA ym. 1970) 


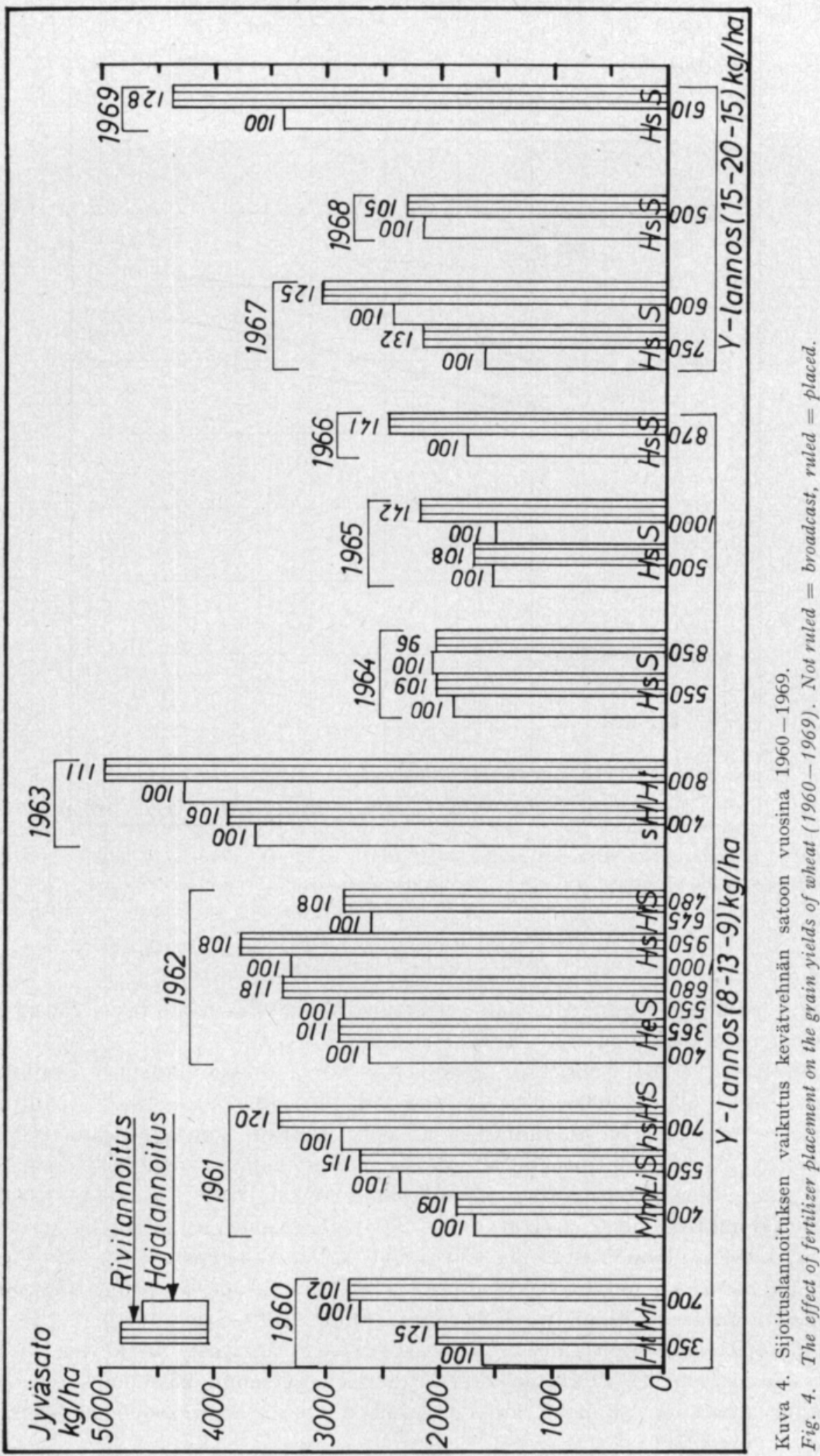


Runsaanla1sta lannoitusta käytettäessä siemenen joukkoon sijoitettu lannoite vaikutțaa haitallisesti siemenen itämiseen ja orastumiseen sekä hidastuttaa alkukehitystä. HonkavaARA (1946) on todennut rukiin orastumisen pienentyneen $93 \%$ :sta $75 \%$ :iin, kun superfosfaattimäärää lisättiin 50 kg:sta 200 kg:aan hehtaaria kohden. Yksiravinteisista lannoitteista kaliumin ja typen yhdisteet ovat itävyydelle haitallisempia kuin fosfaatit (OLson ja DREIER 1956). Suurimpana syynä myrkkyvaikutuksen ohella on siementen veden saantia rajoittava vesiliukoisten suolojen kokonaismäärä.

Sijoituslannoitus.

1960-luvun alussa rivilannoituksella saatujen erittäin myönteisten tulosten perusteella aloitettiin maassamme järjestelmällinen koe- ja tutkimustoiminta eri koeasemilla ja tutkimuslaitoksilla aluksi rivi- ja myöhemmin kylvölannoitukseen liittyvien kysymysten selvittämiseksi. Merkillepantavaa on se ripeys, millä kotimainen teollisuus on käyttänyt hyväkseen tutkimustulokset ja vaikuttanut ratkaisevasti uuden lannoitusmenetelmän yleistymiseen maassamme.

S a t ot a s o. Lannoitteen sijoittamisen satotasoa lisäävä vaikutus on ollut kiistaton lähes kaikissa maassamme suoritetuissa kenttäkokeissa. Sijoituslannoitus on suurentanut kevätvehnän satotasoa Pakankylässä (Espoo) suoritetuissa 10-vuotisissa kokeissa keskimäärin $415 \mathrm{~kg} /$ ha eli $16,1 \%$ (kuva 4). Eri koeasemilla ja tutkimuslaitoksilla suoritetuissa kenttäkokeissa sijoituslannoitus on lisännyt ohran ja kauran suhteellista satoa keskimäärin likimain samalla tavoin kuin vastaavia vehnäsatoja. Ohran ja kauran suoranaiset sadon lisäykset ovat olleet suurempia kuin vehnän niiden paremmasta ominaissatoisuudesta johtuen.

L a n noitustaso. Sijoituslannoituksen tehostuva vaikutus lannoitustasoa nostettaessa on tullut selvästi esille lähes kaikissa maassamme suoritetuissa kenttäkokeissa. Lisättäessä lannoitusta noin 400 kg:sta 800 kg:aan Y-lannosta hehtaaria kohden sijoituslannoituksella saadut sadon lisäykset ovat keskimäärin kaksinkertaistuneet (NiEminen ym. 1967). Heikosti kasvavilla mailla sadon lisäykset ovat jo pienehköjen lannoitemäärien sijoituksen vaikutuksesta olleet tuntuvammat kuin paremmilla mailla (KIvi ja Hovinen 1969, PAUlAmäKI ja Luostarinen 1971). Myös lannoitustason lisääminen vaikuttaa ensiksi mainituilla mailla tehokkaammin.

Paitsi Etelä-Suomen savimailla sijoituslannoitus on eri osissa maata suoritetuissa kokeissa antanut myös turve- ja multamailla huomattavia sadonlisäyksiä, joskin sadon lisäykset ovat Etelä-Suomen savimailla olleet varmimmat (LARPES 1969).

Sijoituslannoitus ja sadet us. Sijoituslannoituksen ja sadetuksen yhteisvaikutusta on tutkittu Pakankylässä hiesusavimaalla seitsemänä vuonna 1964-70 (Elonen ym. 1967 ja KARA ym. 1970) Elonen ja KARA 1972). Taulukkoon 2 on laskettu yhteen kertaan 19-22. 6. sadetettujen koejäsenten satotulokset. Sadetusmäärä on eri vuosina vaihdellut $30-37$ $\mathrm{mm}$. 
Taulukko 2. Sadetuksen vaikutus sijoituslannoituksen tehoon (jyväsadot kg/ha, kosteus $15 \%$ ). Table 2. The effect of sprinkler irrigation and fertilizer placement on the grain yields of wheat, barley and oats (kg/ha, moisture $15 \%$ ).

\begin{tabular}{|c|c|c|c|c|c|}
\hline & \multicolumn{2}{|c|}{$\begin{array}{l}\text { Pintalannoitus } \\
\text { Broadcasting }\end{array}$} & \multicolumn{2}{|c|}{$\begin{array}{c}\text { Sijoituslannoitus } \\
\text { Placement }\end{array}$} \\
\hline & & $\begin{array}{l}\text { ei sadetettu } \\
\text { not irrigated }\end{array}$ & $\begin{array}{l}\text { sadetettu } \\
\text { irrigated }\end{array}$ & $\begin{array}{l}\text { ei sadetettu } \\
\text { not irrigated }\end{array}$ & $\begin{array}{l}\text { sadetettu } \\
\text { irrigated }\end{array}$ \\
\hline Vehnä (6 v.) & | $\mathrm{kg} / \mathrm{ha}$ & 2080 & 2950 & 2460 & 3430 \\
\hline Wheat (6 years) & j sl. - rel. value ...... & 100 & 142 & 118 & 165 \\
\hline Ohra (3 v.) & 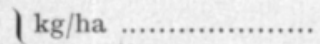 & 2850 & 4080 & 3350 & 4660 \\
\hline Barley (3 years) & f sl. - rel. value ...... & 100 & 143 & 118 & 163 \\
\hline Kaura (1 v.) & | kg/ha ....................... & $3: 140$ & 4730 & 3450 & 5010 \\
\hline Oats (1 years) & sl. - vel. value ....... & 100 & 151 & 110 & 160 \\
\hline
\end{tabular}

Taulukosta 2 ilmenee, että lannoitteen sijoittaminen on lisännyt kevätviljasatoja lähes yhtä paljon sadetetuilla kuin sadettamattomilla koeruuduilla, sadetettujen tuntuvasti korkeammasta satotasosta huolimatta. Rivilannoituksen ja sadetuksen yhteisvaikutus on lisännyt vehnän ja ohran satotasoa n. $65 \%$ ja kauran $60 \%$ (1 koevuosi) hajalannoitettuun sadettamattomaan verrattuna.

Sijoituslannoituksen suhteen on usein arveltu, että sen teho jää hajalannoitukseen verrattuna tuntuvasti pienemmäksi, jos sadetta saadaan riittävästi. Näiden kokeiden perusteella on kuitenkin todettu sijoituslannoituksen ja sadetuksen täydentävän toisiaan niin, että sijoituslannoitus vaikuttaa tehokkaimmin heti oraalle tulon jälkeen, kun taas paras sadetusaika alkaa $2-3$ viikkoa myöhemmin, koska kasvit pystyvät alkukesästä käyttämään sijoitettua lannoitetta sadettamattakin (Elonen ym. 1967).

Kasvuston kehitys ja ravinteiden otto. Kun kylvömuokkaus on suoritettu kunnolla sijoituslannoituksen ei yleensä ole todettu vaikuttavan ainakaan sanottavasti orastuvuuteen. Versojen väri on sijoituslannoitetuilla ruuduilla lähes poikkeuksetta ollut selvästi tummemman vihreää kuin hajalannoitetuilla. Nämä värierot ovat säilyneet lähes koko kasvullisen kehitysjakson ajan.

Laihon kuivapainoa sijoituslannoitus on lisäänyt tuntuvasti hajalannoitukseen verrattuna (AURA 1967). Varhaisemmassa kehitysvaiheessa sijoituslannoitettujen ruutujen eri lannoitustasoilla ei näissä Pakankylän kokeissa ole ollut vaikutusta. Myöhemmässä kehitysvaiheessa lannoitustason nostaminen on vaikuttanut tuntuvasti sijoituslannoitettujen ruutujen laihon kuivapainoon. Samansuuntaisia tuloksia on saatu Tammiston kokeissa (Krvi ja Hovinen 1969).

Paitsi maanpäällisten kasvinosien painoa, sijoituslannoitus on lisännyt suhteellisesti yhtä paljon myös juuriston painoa. Sijoituslannoitus on vaikuttanut juuriston sijaintiin niin, että pääosa muokkauskerroksen juuristoa on hakeutunut lannoiterivien ympärille sijoitussyvyyteen (KäHÄRI ja ELONEN 1969). 
Sijoituslannoitus on lisännyt Pakankylän kokeissa erityisesti ohran mutta jossain määrin myös vehnän pensastumista kuten Tammiston kokeissakin. Sijoituslannoituksen vaikutus kasvuston rehevyyteen on ilmennyt myös korren ja tähkän pituuden lisääntymisenä.

Lannoitteiden sijoittaminen lisää suhteellisesti eniten viljakasvien typen ottoa, jonkin verran vähemmän kalsiumin ottoa ja vähiten fosforin ottoa (Aura 1967, Pessi ym. 1970).

Sadetuksen ja typpilannoituksen sijoituksen vaikutusta koskevissa tutkimuksissa (KAILA ja Elonen 1970) poikkeuksellisen kuivana kesänä 1969 jyväsatojen perusteella laskettu lannoitetypen (120 N kg/ha) hyväksikäyttö oli vain $30 \%$ hajalannoituksena annetusta typestä. Sijoitus lisäsi hyväksikäytön $42 \%: k s i$, sadetus $52 \%: \mathrm{ksi}$ ja molemmat toimenpiteet yhdessä $61 \%: \mathrm{ksi}$. Sadetuksen vaikutus on siis ollut tehokkaampi kuin sijoituksen, mutta molemmat yhdessä ovat antaneet parhaan tuloksen.

Jyväsa don la a t u. Sijoituslannoituksen jyvien puintikosteutta pienentävä eli tuleentumista jouduttava vaikutus on eräitä poikkeuksia lukuunottamatta käynyt selvästi ilmi lähes kaikissa maassamme tehdyissä kenttäkokeissa. Sijoituslannoitus on Pakankylän kokeissä (Elonen ym. 1967, KARA ym. 1970) pienentänyt vehnän jyvien kosteutta (10 v. kokeet) keskimäärin 1,9 \%-yksikköä, ohran (4 v.) 1,2 ja kauran (3 v.) 1,9\%-yksikköä. Ainoastaan poikkeuksellisen kuivana kasvukautena 1969, jolloin sijoituslannoitus ilmeisesti esti kuivuudesta johtuvan »hätätuleentumisen», vehnän puintikosteus on sijoituslannoitetuilla koeruuduilla ollut 2,8\%-yksikköä suurempi kuin hajalannoitetuilla. Sijoituslannoitus on alentanut jyvien kosteuspitoisuutta samalla tavoin lannoitustasosta riippumatta.

Jyvien kokoon ja tilavuuspainoon sijoituslannoituksella ei keskimäärin ottaen liene sanottavaa vaikutusta. Eräissä kokeissa sijoituslannoitus on suurentanut sekä tilavuuspainoa että jyvän kokoa (ELONEN ym. 1967, KöYLIJÄRvi 1969), kun taas vastaavasti toisissa kokeissa suunta on ollut päinvastainen (KIvi ja Hovinen 1969, KARA ym. 1970). Vihreiden jyvien osuutta sijoituslannoitus on pienentänyt tasaisemman tuleentumisen seurauksena yleensä melko tuntuvasti (KöYLIJÄRvi 1969). Ero hajalannoitettuun verrattuna on ollut suurin niinä vuosina jolloin tuleentuminen on ollut epätasaista.

Rivilannoituksen on useimmissa kenttäkokeissa todettu alentaneen kevätviljojen raakavalkuaispitoisuutta. Pakankylän kokeissa vehnän raakavalkuaispitoisuus on sijoituksen vaikutuksesta pienentynyt $1,6 \%$, ohran n. $0,5 \%$ ja kauran $0,3 \%$. Typpilannoitustasoa nostettaessa jyvien raakavalkuaispitoisuuden aleneminen on jossain määrin lieventynyt. 


\section{KIRJALLISUUS}

AUrA, E. 1967. Effect of the placement of fertilizer on the development of spring wheat. J. Scient. Agric. Soc. Finl. 39: 149-155.

Elonen, P. \& KARA, O. 1972. Sprinkler irrigation on clay soils in Southern Finland. IV. The effect of repeated applicatiens of water and nitrogen fertilization on spring cereals. J. Scient. Agric. Soc. Finl. 44: 149-163.

- - Nieminen, L. \& KarA, O. 1967. Sprinkler irrigation on clay soils in southern Finland. I-III. J. Scient. Agric. Soc. Finl. 39: 67-98.

Hernonen, R. 1965. Văkilannoitteiden rivimultauskoneista ja koneyhdistelmistä. Maatalous 4: 74-76.

- - - \& Nieminen, L. 1961. Väkilannoitteiden rivikylvö. Maatal. ja Koetoim. 4: 124-134.

Honkavaara, T. 1945. Pula-ajan menetelmä fosforilannoitukseen. Koetoim. ja Käyt. 4:1-2.

- - 1946. Fosfaattien levittäminen kylvősiemenen mukana. Koetoim. ja Käyt. 4:12.

KaIlA, A. \& Elonen, P. 1970. Influence of irrigation and placement of nitrogen fertilizers on the uptake of nitrogen by spring wheat. J. Scient. Agric. Soc. Finl. 42: 123-130.

- - \& Hänninen, P. 1961. Fertilizer nitrogen in soil. J. Scient. Agric. Soc. Finl. 33: 169184.

KARA, O., RärsäNen, L. \& PALOMÃKI, A. 1970. Rivilannoitus sekä rivi- ja kylvö-lannoituskoneet. Vakolan tiedote 11: $1-12$.

Kıvı, E. \& HoviNEN, S. 1969. Lajikkeen ja, lannoitustavan vaikutus kevätvehnän viljelyarvoon. J. Scient. Agric. Soc. Finl. 4 $9: 258-274$.

KäHÄRI, J. \& ELONEN, P. 1969. Effect of placement of fertilizer and sprinkler irrigation on the development of spring cereals on the basis of root investigations. J. Scient. Agric. Soc. Finl. 41: 89-104.

KöYLıJ ÄRVı, J. 1969. Rivilannoitus kevätviljasatojen varmentajana. Pellervo 70: 204-207.

LARPES, G. 1969. Rivilannoitus valtaa alaa maan keski- ja pohjoisosissakin. Koetoim. ja käyt. 4: 16 .

NiEMINEN, L. 1964. Det lönar sig att utveckla placeringsmaskiner för handelgödsel. Växtnäringsnytt $1: 14-17$.

- , - \& HeINonen, R. 1960. Väkilannoitteiden riviinkylvökoneista. Koetoim. ja Käyt. 12: $37-40$

- - Kara, O. \& Elonen, P. 1967. Kokemuksia sijoituslannoituksesta. Maatal. ja Koetoim. 21: $42-49$.

Olson, R. \& Dreier, A. 1956. Fertilizer placement for small grains in relation to crop stand and nutrient efficiency in Nebraska. Soil Sci. Soc. Amer. Proc. 20: 19-24.

Paulamäki, E. \& Luostarinen, H. 1971. Fertilizer drilling on peat soils. Acta Agr. Fenn. 123: $167-172$.

Pessi, Y., Ylänen, M., Leskelä, A. \& SyväLahti, J. 1970. Results of tests made with placement fertilization on the Kotkaniemi Experimental Farm. J. Scient. Agric. Soc. Finl. 42: $193-202$.

SALONEN, M. 1960. Salpietarin multaus vaiko käyttō pintalannoituksena. Koetoim. ja Käyt. 5: $17-20$. 